\title{
Hubungan Derajat Akne Vulgaris dengan Kepatuhan Pengobatan pada Mahasiswa di Fakultas Kedokteran Universitas Riau
}

\author{
Alida Widiawaty, ${ }^{1 *}$ Zahtamal, ${ }^{2}$ Normalina Sandora, ${ }^{1}$ Amelinda, ${ }^{3}$ Mugen Adi Suryo, ${ }^{3}$ Sysca Priastiwi ${ }^{3}$
}

\begin{abstract}
S
Successful treatment of acne vulgaris (AV) can impact patient's quality of life. AV treatment outcome is associated with the patient adherence. The aim of this study was to know the association between acne vulgaris and adherence among medical students of Universitas Riau. The samples were students with AV according to inclusion criteria as 39 respondents. In this study, respondents got check the grade of the AV according to Lehmann classification, the adherence was measured using the translation and modification of Elaboration d'un outil d'evaluation de l'observance des traitements medicamenteux (ECOB) Questionnaire that has been tested. In this study, mild AV was found among $69.23 \%$ of the respondents as the most AV grade found among the respondents. Adherence rate was found to be poor as $53.85 \%$ of the respondents have poor adherence to medication. Statistic test showed there was a correlation between AV grade and adherence with the p-value of $0,006(\mathrm{p}<0,05)$.
\end{abstract}

Keywords: acne vulgaris, adherence, treatment

Akne vulgaris (AV) adalah penyakit peradangan menahun unit pilosebasea yang bersifat swasirna, ditandai dengan lesi pleomorfik berupa papul, komedo, pustul, dan nodul. Tempat predileksi pada wajah, dada, punggung, dan lengan atas. Prevalensi terbanyak (sekitar 85\%) terjadi pada remaja dan dewasa muda, terutama usia 11-30 tahun. ${ }^{1-4}$ Pengobatan AV memerlukan waktu yang cukup lama, sehingga dapat memengaruhi psikologis dan mengganggu kualitas hidup pasien dalam bentuk kesedihan, rasa marah, frustasi, kecemasan, depresi, dan penarikan diri dari lingkungan. ${ }^{5}$ Pengeobatan AV yang lama berdampak terhadap kepatuhan pasien.

Menurut World Health Organization (WHO), kepatuhan (adherence) didefinisikan sebagai perilaku seseorang dalam mengonsumsi obat, mengikuti diet, atau melakukan perubahan gaya hidup sehat sesuai anjuran tenaga kesehatan yang telah disepakati bersama. ${ }^{6-8}$ Ketidakpatuhan dapat mengakibatkan kegagalan pengobatan dalam bentuk perburukan penyakit, peningkatan biaya pengobatan, bahkan sampai kematian. ${ }^{6}$ Angka kepatuhan

\footnotetext{
* Penulis untuk korespondensi : widiawatyalida@gmail.com

1 KJF Biologi Kedokteran Fakultas Kedokteran Universitas Riau, Pekanbaru

2 KJF IKM-KK Fakultas Kedokteran Universitas Riau, Pekanbaru

3 Fakultas Kedokteran Universitas Riau, Pekanbaru
}

pengobatan pasien lebih tinggi pada penyakit akut dibandingkan dengan penyakit menahun dan lebih baik pada pengobatan oral dibandingkan dengan topikal. ${ }^{6,9-11}$ Pilihan lini pertama pengobatan AV adalah obat-obatan topikal dengan atau tanpa obat oral sesuai derajat penyakit yang membutuhkan waktu minimal antara 6-8 minggu, di antara ketiga derajat $\mathrm{AV}$, hanya $\mathrm{AV}$ ringan (AVR) yang diterapi dengan obat-obatan topikal saja. Kepatuhan pengobatan pada AV merupakan masalah utama dalam tatalaksana pasien karena waktu pengobatan lama dengan perbaikan yang lambat. Hampir sama dengan pengobatan penyakit kronik lain, ketidakpatuhan pengobatan merupakan penyebab utama kegagalan pengobatan AV. Kepatuhan berobat pasien AV hanya berkisar antara 30\% - 50\%, dan ternyata semakin menurun sesuai dengan penurunan derajat keparahannya. Pasien AV berat (AVB) lebih patuh berobat dibandingkan dengan AVR dan AV sedang (AVS). ${ }^{2-5,12}$

Akne vulgaris merupakan penyakit kulit peringkat 3 terbanyak di dunia setelah dermatitis dan psoriasis. ${ }^{13,14}$ Pada tahun 2010, jumlah kasus baru AV di Rumah Sakit Cipto Mangunkusumo (RSCM) sebesar 30,7\% dengan jumlah terbanyak kelompok usia 15-24 tahun dan berdasarkan derajat keparahannya yang terbanyak adalah kasus AVR 
dan AVS (86\%). Prevalensi AVR di Negara maju menduduki peringkat tertinggi pada kelompok usia remaja. $^{4}$

Kepatuhan pengobatan dipengaruhi oleh berbagai faktor, yaitu sistem pelayanan kesehatan, pengobatan, pasien, sosial ekonomi, dan kondisi lingkungan. Beberapa di antara faktor-faktor tersebut dapat berupa sulitnya akses ke tempat layanan kesehatan, edukasi terhadap pasien yang kurang memadai, stres yang timbul karena kunjungan ke klinik, pengobatan yang rumit, terapi jangka panjang, dan stigma masyarakat terhadap pengobatan penyakit. ${ }^{6-8}$ Sampai saat ini masih sulit untuk menilai kepatuhan pasien dan pengukuran pola kepatuhan yang akurat dan dapat dipercaya..$^{15}$ Berbagai cara telah diteliti, termasuk pada AV. Sampai saat ini belum ditemukan metode standar untuk mengevaluasi kepatuhan pengobatan AV. Penelitian yang telah dilakukan adalah dengan menggunakan kuesioner, pengukuran berat obat topikal, dan penggunaan pesan singkat elektronik. ${ }^{16-18}$ Cara yang dilakukan untuk menilai kepatuhan pasien AV secara cepat adalah dengan menggunakan kuesioner mini. Cara ini dapat dengan mudah mengidentifikasi ketidakpatuhan pengobatan dengan spesifisitas sebesar $89 \% .^{14}$

Mahasiswa merupakan kelompok usia remaja berkisar 16-23 tahun. Mereka merupakan kelompok terbanyak yang mudah terkena AV. Pada sela-sela kesibukan dan kegiatan belajar yang padat tentunya mahasiswa dengan AV perlu meluangkan waktu untuk memerhatikan kondisi wajahnya agar pengobatannya berhasil. Khususnya mahasiswa kedokteran dengan kegiatan yang menuntut konsentrasi tinggi. Untuk itu perlu dilakukan analisis mengenai hubungan antara derajat AV dengan kepatuhan pengobatannya.

Penelitian ini bertujuan untuk mengetahui hubungan derajat akne vulgaris dengan kepatuhan pengobatan pada mahasiswa Fakultas Kedokteran Universitas Riau (FK UNRI).

\section{METODE}

Penelitian ini merupakan studi analitik dengan desain cross sectional untuk mengetahui hubungan derajat AV dengan kepatuhan pengobatan. Penelitian ini dilakukan dari bulan Juli sampai November 2017. Subyek penelitian (SP) ini diambil dari populasi terjangkau yaitu mahasiswa FK UNRI yang terpilih berdasarkan kriteria pemilihan sampel. Sampel diambil dengan cara total sampling, yaitu seluruh populasi terjangkau yang memenuhi kriteria inklusi dan ekslusi dimasukkan sebagai SP dengan total sampel 30 orang. Kriteria inklusi penelitian ini adalah mahasiswa FK UNRI yang didiagnosis AVR, AVS, atau AVB; bersedia ikut dalam penelitian dan menandatangani informed consent penelitian. Subjek penelitian juga harus pernah menjalani pengobatan AV ke dokter umum atau dokter spesialis kulit dan kelamin minimal 1 bulan dalam 6 bulan terakhir. Kriteria eksklusi penelitian ini adalah mahasiswa yang terduga dan atau didiagnosis kondisi hiperandrogenisme, misalnya polycystic ovarium syndrome atau Sindrom Cushing.

Sebelum memulai penelitian, terlebih dahulu dilakukan penyaringan SP. Sampel yang memenuhi syarat kemudian menandatangani formulir persetujuan penelitian, lalu dilakukan anamnesis terpadu. Pemeriksaan fisik pada SP meliputi pemeriksaan status lokalis pada wajah dengan menghitung dan menilai lesi AV untuk menentukan derajat AV sesuai kriteria Lehmann. Masing-masing hasil pemeriksaan SP didokumentasikan dengan memotret lesi dalam 3 posisi wajah dengan menggunakan kamera. Subjek penelitian kemudian diberikan kuesioner dan diminta untuk mengisi seluruh pertanyaan yang ada. Kuesioner yang digunakan adalah kuesioner modifikasi Elaboration d'un outil d'evaluation de l'observance des traitements medicamenteux (ECOB) yang sudah divalidasi. ${ }^{12}$

\section{HASIL}

Jumlah SP yang mengikuti penelitian dan memenuhui kriteria inklusi dan ekslusi sebanyak 39 orang. Karakteristik SP dapat dilihat pada Tabel 1. 
Tabel 1. Subjek Penelitian

\begin{tabular}{lcc}
\hline Karakteristik & Jumlah & $\%$ \\
\hline Umur & & \\
16 tahun -19 tahun & 16 & 41,02 \\
20 tahun -24 tahun & 23 & 58,98 \\
\hline Total & 39 & 100 \\
\hline Jenis Kelamin & & 20,51 \\
Laki-laki & 8 & 79,49 \\
Perempuan & 31 & 100 \\
\hline Total & 39 & \\
\hline
\end{tabular}

Berdasarkan Tabel 1 didapatkan bahwa umur responden yang terbanyak adalah umur 20-24 tahun sebesar 58,98 \% dari total responden, jenis kelamin

Tabel 2. Gambaran derajat AV pada mahasiswa FK UNRI

\begin{tabular}{lcc}
\hline \multicolumn{1}{c}{ Derajat AV } & Jumlah & Persentase (\%) \\
\hline AV derajat ringan & 27 & 60,24 \\
AV derajat sedang & 6 & 15,38 \\
AV derajat berat & 6 & 15,38 \\
\hline Jumlah & 39 & 100 \\
\hline
\end{tabular}

Berdasarkan Tabel 2 didapatkan bahwa derajat AV terbanyak pada mahasiswa FK UNRI yaitu derajat ringan sebanyak 27 responden dengan yang terbanyak adalah perempuan dengan jumlah respoden sebesar 79,49 \% dari total responden.

Tabel 3. Gambaran kepatuhan pengobatan AV pada mahasiswa FK UNRI

\begin{tabular}{lcc}
\hline \multicolumn{1}{c}{ Kepatuhan } & Jumlah & Persentase $(\%)$ \\
\hline Patuh & 18 & 46,15 \\
Tidak Patuh & 21 & 53,85 \\
\hline Jumlah & 39 & 100 \\
\hline
\end{tabular}

Berdasarkan Tabel 3 didapatkan bahwa kepatuhan pengobatan AV pada mahasiswa FK persentase sebesar 69,24\%, derajat AV yang paling sedikit yaitu kategori sedang dan berat, masingmasing 15,38\%.

Tabel 4. Gambaran kepatuhan pengobatan berdasarkan derajat AV pada mahasiswa FK UNRI

\begin{tabular}{|c|c|c|c|c|c|c|}
\hline & & & \multicolumn{2}{|c|}{ Kepatuhan } & \multirow{2}{*}{ Total } & \multirow{2}{*}{$\mathrm{p}$} \\
\hline & & & Tidak Patuh & Patuh & & \\
\hline \multirow[t]{6}{*}{ Derajat AV } & Derajat Ringan & Jumlah (N) & 10 & 17 & 27 & $0,006^{*}$ \\
\hline & & Persentase $(\%)$ & $37 \%$ & $63 \%$ & $69,24 \%$ & \\
\hline & Derajat Sedang & Jumlah (N) & 5 & 1 & 6 & \\
\hline & & Persentase $(\%)$ & $83,3 \%$ & $16,7 \%$ & $15,38 \%$ & \\
\hline & Derajat Berat & Jumlah (N) & 6 & 0 & 6 & \\
\hline & & Persentase $(\%)$ & $100 \%$ & $0 \%$ & $15,38 \%$ & \\
\hline \multirow[t]{2}{*}{ Total } & & Jumlah (N) & 21 & 18 & 39 & \\
\hline & & Persentase $(\%)$ & $53,85 \%$ & $46,15 \%$ & $100 \%$ & \\
\hline
\end{tabular}

\footnotetext{
*diuji dengan Chi-Square
}

UNRI yang didapatkan dari 39 responden yaitu 46,25 \% patuh dan 53,85 \% tidak patuh. 
Berdasarkan Tabel 4, didapatkan bahwa kepatuhan pengobatan berdasarkan derajat AV terbanyak terdapat pada criteria AV derajat ringan sebanyak 27 responden dengan persentase sebesar 69,24\% dari total responden dengan pasien dengan kriteria tidak patuh dan patuh secara berurutan sebanyak 10 dan 17 responden. Hasil uji statistik chi square didapatkan nilai $\mathrm{P}$ value sebesar 0,006 $(\mathrm{p}<0,05)$. Hal ini menunjukkan bahwa terdapat hubungan yang signifikan antara derajat $\mathrm{AV}$ dan kepatuhan pengobatan AV pada mahasiswa FK UNRI.

\section{PEMBAHASAN}

Pada penelitian ini didapatkan responden sebanyak 39 orang. Hasil penelitian pada Tabel 1 didapatkan penderita $\mathrm{AV}$ terbanyak pada kelompok umur 20-24 tahun adalah 58,98\%. Hal ini sesuai dengan Allayali tahun 2017 bahwa kelompok terbanyak yang menderita AV pada mahasiswa kedokteran yaitu pada kelompok umur 20-24 tahun sebesar $66,7 \% .{ }^{19}$ Hal ini sejalan dengan penelitian Yi et al. Tahun 2014 didapatkan bahwa prevalensi AV terbanyak ditemukan pada umur 7-12 (masa pubertas) kemudian akan menurun dan kemudian akan meningkat kembali di umur 19 tahun ke atas. Hal ini sesuai dengan hasil penelitian pada Tabel 1 bahwa ditemukan adanya peningkatan insidensi AV dari 41,02\% pada kelompok umur 16-19 tahun menjadi 58,98\% pada kelompok umur 20-24 tahun. ${ }^{20}$ Hasil penelitian oleh Sarfriyanda menunjukkan bahwa mahasiswa umumnya terdiri dari kelompok dewasa muda (18-25 tahun) dengan jumlah mahasiswa yaitu 99\% merupakan kelompok dewasa muda. $^{21}$

Pada Tabel 1 didapatkan penderita AV pada laki-laki sebanyak 20,51\% dan perempuan sebanyak 79,49\%. Hasil penelitian ini sesuai dengan penelitian Yi et al. Tahun 2014 bahwa rasio penderita AV pada umur 13-24 tahun yaitu 28,79\% pada laki-laki dan $71,2 \%$ pada perempuan. Hal ini sedikit berbeda dengan hasil penelitian oleh Bagatin, bahwa tidak ada perbedaan epidemiologis AV antara laki-laki dan perempuan. Hal ini dapat disebabkan karena penelitian ini hanya pasien yang melakukan pengobatan yang dimasukkan kedalam kriteria responden, hal ini dapat berpengaruh karena tidak semua orang yang menderita AV melakukan pengobatan. ${ }^{20,22} \mathrm{Hal}$ ini berhubungan dengan penelitian oleh Darwish, karena perempuan lebih memperhatikan kesehatan yang berhubungan dengan kulitnya dibandingkan laki-laki (perempuan 63,9\%, laki-laki 40,3\%). ${ }^{23}$

Berdasarkan hasil penelitian didapatkan bahwa derajat AV yang paling banyak ditemukan yaitu AV derajat ringan yaitu sebesar 69,23\%. Hasil penelitian ini sesuai dengan penelitian Ghodsi tahun 2009 bahwa $\mathrm{AV}$ derajat ringan merupakan derajat $\mathrm{AV}$ yang paling banyak ditemukan pada umur 12-20 tahun yaitu sebanyak $79,1 \%{ }^{24}$

Berdasarkan hasil penelitian didapatkan bahwa kepatuhan pengobatan AV yang buruk mencapai $53,85 \%$. Hal ini sesuai dengan penelitian yang dilakukan oleh Dreno pada tahun 2010 bahwa angka ketidakpatuhan pada pengobatan AV dapat mencapai $50 \%$. Beberapa hal yang memengaruhi ketidakpatuhan pada pengobatan AV ini sendiri disebabkan responden yang umumnya merupakan kelompok remaja dan dewasa muda, berdasarkan penelitian oleh Furue et al. Tahun 2015 salah satu faktor yang menyebabkan ketidakpatuhan adalah umur yang masih muda. ${ }^{25}$ Selain itu, munculnya efek samping yang tidak diinginkan, penyembuhan yang lama, pengetahuan pasien yang kurang, dan ketidakpuasan terhadap pengobatan AV juga dapat menyebabkan ketidakpatuhan pada penyakit $\mathrm{AV} .{ }^{12}$

Untuk mencegah resistensi terhadap pengobatan AV, diperlukan kepatuhan pengobatan yang baik. Riwayat putus obat terutama dalam menggunakan antibiotik dapat menyebabkan resistensi, menurunkan keberhasilan pengobatan, dan membengkaknya biaya pengobatan. ${ }^{26}$ Hasil penelitian oleh Sardana di India Tahun 2016 menunjukkan bahwa angka resistensi Propionibacterium acnes terhadap makrolida sangat tinggi (98\% eritromisin, 90,4\% klindamisin, dan $100 \%$ azitromisin). ${ }^{27}$

Dalam penatalaksanaan AV, selain farmakoterapi, peran dokter sangat penting. Penelitian oleh Widiawaty menyatakan bahwa kepatuhan pengobatan AV terutama AV derajat ringan dapat ditingkatkan dengan memberikan pesan singkat elektronik. ${ }^{18}$ Selain pesan singkat elektronik, hasil penelitian oleh Park Tahun 2014 menyatakan pesan singkat elektronik dapat dikombinasikan dengan teknologi internet dan survey untuk 
meningkatkan kepatuhan pengobatan pasien. Berdasarkan teori, kepatuhan pengobatan pasien akan memengaruhi keberhasilan pengobatan $\mathrm{AV}{ }^{28}$

Hasil penelitian didapatkan bahwa kepatuhan pengobatan pada AV derajat ringan memiliki angka kepatuhan yang lebih tinggi yaitu 63\%. Hasil ini penelitian ini sesuai dengan penelitian oleh Widiawaty tahun 2015 bahwa angka kepatuhan AV derajat ringan yaitu 63,5\%. Hasil ini sedikit berbeda dengan penelitian yang dilakukan oleh Dreno, disebutkan bahwa kepatuhan pengobatan AV derajat ringan cenderung rendah. Kepatuhan pengobatan merupakan suatu tindakan aktif antara dokter dan pasien agar pasien dapat mengkonsumsi obat sesuai yang diedukasikan, sehingga menggunakan pesan singkat elektronik dapat meningkatkan kepatuhan pengobatan pasien $\mathrm{AV}$ derajat ringan dibandingkan $\mathrm{AV}$ derajat berat. ${ }^{12,18}$

Setelah dilakukan uji kemaknaan dengan menggunakan uji chi-square pada Tabel 4, didapatkan hubungan yang bermakna antara derajat AV dengan kepatuhan pengobatan AV mahasiswa FK UNRI dengan $\mathrm{p}<0,05(0,006)$. Hal ini sesuai dengan penelitian yang dilakukan oleh Dreno B bahwa derajat AV dapat memengaruhi kepatuhan pengobatan yang didapat. ${ }^{12}$

Berdasarkan hasil penelitian kepatuhan pengobatan AV derajat ringan lebih tinggi dibandingkan derajat sedang dan berat. Hal ini dapat disebabkan karena pada AV derajat berat pengobatan pasien menggunakan pengobatan kombinasi oral, menurut Miyachi tahun 2011 kepatuhan kombinasi oral pada AV lebih rendah dibandingkan kepatuhan pengobatan topikal yaitu 80\% dari total 275 responden memiliki kepatuhan pengobatan buruk. Menurut Miyachi, hal ini dapat disebabkan pasien dengan derajat AV yang berat cenderung tidak merasakan hasil pengobatan yang diberikan ( $\mathrm{OR}=3,59)$, penggunaan obat topikal tidak beresep (OR 1,75), dan efek samping (OR 1,71). ${ }^{29}$ Ketidakpatuhan pasien AV derajat berat dapat disebabkan keharusan pasien untuk melakukan kunjungan ke layanan kesehatan lebih banyak dibandingkan derajat ringan dan sedang. Penelitian oleh Tan et al. menunjukkan faktor yang dapat menyebabkan ketidakpatuhan pasien AV adalah biaya pengobatan dan pasien yang memiliki pendapatan yang rendah. Menurut Tuchayi Tahun
2016 pengobatan AV memerlukan waktu yang panjang (minggu hingga bulan), sehingga pasien cenderung untuk memikirkan bahwa pengobatannya tidak berhasil. Suatu penelitian dengan menggunakan biaya pengobatan menunjukkan bahwa angka kepatuhan pasien menurun dari $86 \%$ pada minggu pertama menjadi $36 \%$ setelah 6 minggu pengobatan. ${ }^{30,31}$ Penting untuk memberikan edukasi pada pasien-pasien AV bahwa pengobatan AV memerlukan waktu yang panjang, karena kepatuhan pengobatan baik akan berpengaruh dengan keberhasilan pengobatan $\mathrm{AV}^{28}$

\section{KESIMPULAN}

Derajat AV terbanyak pada mahasiswa FK UNRI adalah AV derajat ringan. Tingkat kepatuhan pengobatan AV pada mahasiswa FK UNRI mayoritas tidak patuh. Terdapat hubungan antara derajat AV dan kepatuhan pengobatan AV.

\section{UCAPAN TERIMA KASIH}

Ucapan terima kasih disampaikan kepada FK UNRI yang telah membantu dalam mendanai penelitian ini.

\section{DAFTAR PUSTAKA}

1. Zaenglein AL, Graber EM, Thiboutot DM. Acne vulgaris and acneiform eruptions. Dalam: Goldsmith LA, Katz SI, Gilchrest BA, Paller AS, Leffel DJ, Wolff K. Fitzpatrick's Dermatology in general medicine, $8^{\text {th }}$ edition. New York: McGraw-Hill, 2012. h. 897-917.

2. Gollnick H, Cunliffe W, Berson D, Dreno B, Finlay A, Leyden JJ, et al. Management of acne: a report from a Global Alliance to improve outcomes in acne. J Am Acad Dermatol 2003; 49:1-18.

3. Thiboutot D, Gollnick H, Bettoli V, Dréno B, Kang S, Leyden JJ, et al. New insight into management of acne: an update from the Global Alliance to improve outcomes in acne group. J Am Acad Dermatol 2009;60:1-17.

4. Nast A, Dréno B, Bettoli V, Degitz K, Erdman R, Finlay AY, et al. Europian Evidence-based (S3) 
guidelines for the treatment of acne. J Eur Acad Dermatol Venereol 2012;26:1-29.

5. Lott R, Taylor SL, O’Neill JL, Krowchuk DP, Feldman SR. Medication adherence among acne patients: a review. J Cosm Dermatol 2010;9:1606.

6. Osterberg L, Blaschke T. Adherence to medication. N Eng J Med 2005;353:487-97.

7. World Health Organization. Adherence to longterm therapies: evidence for action, 2003.

8. Clinical service proposal medication adherence services. British Columbia Pharmacy Association (BCPhA), 2013.

9. Krejci-Manwaring J, McCarthy MA, Camacho FT, Carrol CL, Johnson K, Manuel J, et al. Adherence with topical treatment is poor compared with adherence with oral agents: implications for effective clinical use of topical agents. J Am Acad Dermatol 2006;54:S235-6.

10.Balkrishnan R. The importance of medication adherence in improving chronic-disease related outcomes. Med Care 2005;43:517-20.

11. Serup J, Lindblad A, Maroti M, Kjellgren K, Niklasson E, Ring L, et al. To follow or not to follow dermatological treatment: a review of the literature. Acta Derm Venereol 2006;86:193-7.

12. Dréno B, Thiboutot D, Gollnick H, Finlay AY, Layton A, Leyden JJ, et al. Large-scale worldwide observational study of adherence with acne therapy. Int J Dermatol 2010;49:448-56.

13. Hay RJ. Global health in dermatology. Dalam: Goldsmith LA, Katz SI, Gilchrest BA, Paller AS, Leffel DJ, Wolff K. Fitzpatrick’s Dermatology in general medicine, $8^{\text {th }}$ edition. New York: McGraw-Hill, 2012. h. 15-21.

14.Johns NE, Hay RJ, Wulf S, Naghavi M. A systematic analysis of the global burden of skin disease: lesions learned. Lancet 2013 (abstrak).

15.Greenlaw SM, Yentzer BA, O’Neill JL, Balkrishnan R, Feldman S. Assessing adherence to dermatology treatments: a review of self-report and electronic measures. Skin Res Tech 2010;16:253-8.

16. Pawin H, Beylot C, Chivot M, Faure M, Poli F, Revuz J, et al. Creation a tool to assess adherence to treatments for acne. Dermatology 2009;218:26-32.

17.Zaghloul SS, Cunliffe WJ, Goodfield MJD. Objective assessment of compliance with treatments in acne. Br J Dermatol 2005;152:101521.

18.Widiawaty A, Indriatmi W, Legiawati L. Efektivitas pesan singkat elektronik terhadap kepatuhan pengobatan akne vulgaris ringan di Poliklinik Ilmu Kesehatan Kulit dan Kelamin RSCM. [Tesis]. Universitas Indonesia. 2015

19. Allayali AZ, Asseri BN, Alnodali NI, Alhunaki RNM, Algobian SFG. Assessment of prevalence, knowledge, attitude, and psychosocial impact of acne vulgaris among medical students in Saudi Arabia. J Clin Exp Dermtol Res. 2017;8:4

20. Yang YC, Tu HP, Hong CH, Chang WC, Fu HC, Ho JC, et al. Female gender and acne disease are jointly and independently associated with the risk of major depression and suicide: A National Population-Based Study. Biomed Res Int. 2014;2014:504279

21.Sarfriyanda J, Karim D, Dewi AP. Hubungan antara kualitas tidur dan kuantitias tidur dengan prestasi belajar mahasiswa. JOM. 2015;2:117885

22. Bagatin E, Guadanhim LRdS, Terzian LR, Florez M, Timpano DL, Nogueira VMA, et al. Acne vulgaris: prevalence and clinical forms in adolescents from Sao Paulo, Brazil. An Bras Dermatol. 2014;89(3):428-35

23.Darwish MA, Al-Rubaya AA. Knowledge, belief, and psychosocial effect of acne vulgaris among saudi acne patients. ISRN Dermatol. 2013;2013:929340

24. Ghodsi SZ, Orawa H, Zouboulis CC. Prevalence, severity, and severity risk factors of acne in high school pupils: A community-based study. J Invest Dermatol. 2009;129:2136-41

25. Furue M, Onozuka D, Takeuchi S, Murota H, Sugaya M, Masuda K, Hiragun T, et al. Poor adherence to oral and topical medication in 3096 dermatological patients as assessed by the Morisky Medication Adherence Scale-8. Br J Dermatol. 2015;172:272-5 
26. Wolff K, Goldsmith LA, Katz SI, Gilchrest BA, Paller AS, Leffell DJ. Fitzpatrick’s Dematology in General Medicine seventh edition. United States of America: MC Graw Hill, 2008. h.690703

27. Sardana K, Gupta T, Kumar B, Gautam HK, Garg VK. A cross-sectional pilot study of antibiotic resistence in Propionibacterium acnes strains in Indian acne patients using 16s- RNA polymerase chain reaction: A comparison among treatment modalities including antibiotics, benzoyl peroxide, and isotretinoin. 2016. Indian J Dermatol. 2016; 61(1):45-52

28.Dewi R. Hubungan perawatan kulit wajah dengan timbulnya akne vulgaris [skripsi]. Semarang: Universitas Diponegoro. 2012
29. Miyachi Y, Hayashi N, Furukawa F, Akamatsu $\mathrm{H}$, Matsunaga $\mathrm{K}$, Watanabe $\mathrm{S}$, et al. Acne management in Japan: Study of patient adherence. Dermatology. 2011;223:174-81

30.Tuchayi SM, Alexander TM, Nadkarni A, Feldman SR. Interventions to increase adherence to acne treatment. Dovepress. 2016;10:2091-6

31.Tan X, Al Dabagh A, Davis SA, Lin HC, Balkrishnan R, Chang J, et al. Medication adherence, healthcare costs and utilization associated with acne drugs in medicaid enrollees with acne vulgaris. Am Clin Dermatol. 2013;14:243-51 